\title{
A report of 26 cases of ovarian lesions as seen in a Tertiary Institution in North-East Nigeria
}

'Abdullahi K, 1 Mohammed U, 2Aminu BM, 2Dattijo LM, ${ }^{1}$ Department of Morbid Anatomy \& Forensic Medicine, Faculty of Basic Medical Sciences, College of Health Sciences, Usmanu Danfodiyo University, Sokoto

${ }^{2}$ Departments of Obstetrics and Gynaecology, Abubakar Tafawa Balewa University Teaching Hospital, Bauchi, Nigeria

Correspondence: Dr Kabiru Abdullahi, Department of Morbid Anatomy \& Forensic Medicine, Faculty of Basic Medical Sciences, College of Health Sciences, Usmanu Danfodiyo University, Sokoto. Email: kabileo08@yahoo.com

\begin{abstract}
Background: Ovarian cancer is a lethal disease. Globally, it claims 125,000 lives per year. Non-neoplastic lesions of the ovary frequently mimic ovarian neoplasms; many occur in the reproductive years and may be associated with infertility. The clinical diagnosis of ovarian cancers is still problematic when compared with that of the cervix owing to the fact that the ovary is less accessible and there has been no universally accepted screening protocol.
\end{abstract}

Objectives: To study the pattern and age distribution of non-neoplastic and neoplastic lesions of the ovary in a tertiary institution in North - east Nigeria and compare it with other centers.

Methods: It was a retrospective retrieval of oopherectomy specimens seen over a 1 year period with review of their histopathologic characteristics.

Results: A total of 26 oophorectomy specimens were received within the study period ( $1^{\text {st }}$ January 2012 to $31^{\text {st }}$ December 2012$)$. There were $11(42.3 \%)$ nonneoplastic conditions and 15(57.7\%) neoplastic conditions of which $8(30.8 \%)$ were benign and $7(26.9 \%)$ malignant tumours .The age range of non-neoplastic conditions was 20 to 49 years. Corpus luteum cyst was the most common lesion 4 $(15.4 \%)$ and a case of ovarian ectopic gestation was observed. Neoplastic lesions were predominantly observed in fourth, third and second decades of life with age range of 17 years to 72 years. Papillary serous Cystadenocarcinoma was the most common malignant tumour, 5(19.2\%).

Conclusion: The most common non-neoplastic ovarian lesion was Corpus luteum cyst and the most common benign and malignant ovarian neoplasm was papillary serous Cystadenoma and papillary serous Cystadenocarcima respectively. A further review may be needed in the future to compare epidemiologic trends in the environment

Key words: Ovarian, Neoplastic, non-neoplastic, Lesions

\section{INTRODUCTION}

Five cancers commonly affect the female reproductive organs. These include cervical, ovarian, uterine, vaginal and vulva cancers. Each is unique with respect to symptoms, signs and prognosis.

Organised screening has led to a rapid decline in the incidence, morbidity and mortality of cervical cancer in developed countries. ${ }^{1}$ This does not apply to developing countries where organised and reliable screening protocols not readily available or absent. Cases thus present for the first time at the advanced stage of the disease. $^{2}$

Non-neoplastic lesions of the ovary frequently present as a pelvic mass and are often associated with abnormal hormonal manifestations, thus potentially mimicking an ovarian neoplasm clinically, intraoperatively and pathologically. Many occur in the reproductive years and may be associated with infertility. Their proper recognition is, therefore, important to allow appropriate, usually conservative therapy; thereby avoiding unnecessary oophorectomy. ${ }^{3}$ Cancer of the ovary afflicts nearly 204,000 women 
worldwide each year, including approximately 23,000 Americans. Despite its relative low incidence rate, ovarian cancer is an extremely lethal disease. Globally, it claims 125,000 lives per annum, making it the seventh leading cause of cancer-related deaths among women. ${ }^{4}$ About $80 \%$ of ovarian tumours are benign, and these occur mostly in young women between the ages of 20 and 45 years. Borderline tumours occur at slightly older ages. Malignant tumours are more common in older women, between the ages of 45 and 65 years. ${ }^{5}$

The clinical diagnosis of ovarian cancers is still problematic when compared with that of the cervix owing to less accessibility of the former, with attendant late presentation due to poor early detection. ${ }^{6,7}$

\section{MATERIALSAND METHODS}

The study was a one year retrospective histopathological review of twenty six oophorectomy specimen that were received in the Department of Pathology, Abubakar Tafawa Balewa University Teaching Hospital, Bauchi, Nigeria, from $1^{\text {st }}$ January 2012 to $31^{\text {st }}$ December 2012.

The institution had only just commenced full histopathologic services in the year under review.

Clinical data on each case was extracted from the respective copies of the request cards. The haematoxylin and eosin ( $\mathrm{H}$ and $\mathrm{E}$ ) stained slides were retrieved in each case and reviewed microscopically by the authors. Where slides were missing or broken, fresh sections were taken from the paraffin-embedded tissue blocks of the specimens and stained. Cases in which the bio-data, clinical details, slides or tissue blocks were missing were excluded from the study after futile attempts at obtaining such information. The cases were classified broadly into a non-neoplastic group comprising of functional and pregnancy related lesions. The second category are the Neoplastic lesions were categorised into benign and malignant by using World Health Organization Classification of Tumours (WHO). ${ }^{10} \quad$ The results were presented in tabular form and analysed using simple frequency distribution.

\section{RESULTS}

A total of 26 oophorectomy specimens were received in the Department of Pathology, Abubakar Tafawa Balewa University Teaching Hospital, Bauchi, Nigeria, within the study period. There were $11(42.3 \%)$ nonneoplastic lesions (Table.1) and 15(57.7\%) Neoplastic lesions of which $8(30.8 \%)$ were benign and $7(26.9 \%)$ malignant tumours (Table.II).

Table 1: Distribution of Non-Neoplastic Ovarian Lesions.

\begin{tabular}{lc}
\hline Histological Group & Number of Cases (\%) \\
\hline Corpus luteum cyst & $4(15.4)$ \\
Corpus luteum & $2(7.7)$ \\
Corpus luteum hemorrhagic um & $2(7.7)$ \\
Follicular cyst & $2(7.7)$ \\
Ovarian ectopic gestation & $1(3.9)$ \\
\hline Total & $11(42.3)$ \\
\hline
\end{tabular}

Table II: Distribution of Histological type of Ovarian Neoplastic Lesions.

\begin{tabular}{lc}
\hline Histological Group & Number of Cases (\%) \\
\hline Papillary serous Cystadenocarcinoma & $5(19.2)$ \\
Papillary serous Cystadenoma & $3(11.5)$ \\
Mucinous Cystadenocarcinoma & $1(3.9)$ \\
Mature cystic teratoma & $2(7.7)$ \\
Adult Granulosa cell tumour & $3(11.5)$ \\
Sclerosing stromal tumour & $1(3.9)$ \\
\hline Total & $\mathbf{1 5 ( 5 7 . 7 )}$ \\
\hline
\end{tabular}

The age range of non-neoplastic conditions was 20 to 49 years (Figure 1). Corpus luteum cyst was the most common non-neoplastic 
lesions $4(15.4 \%)$, Corpus luteum, Corpus luteumhemorrhagicum and Follicular cyst account for $2(7.7 \%)$ each. A case of ovarian ectopic gestation was observed.

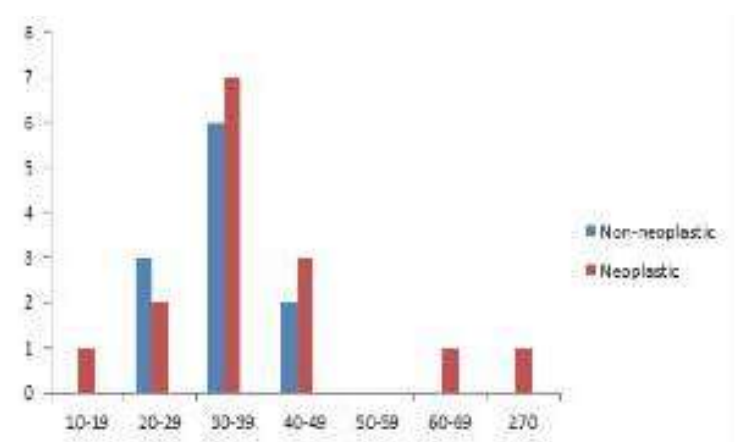

Figure 1: Age distribution of the Neoplastic and non-Neoplastic ovarian lesions

Neoplastic lesions were predominantly observed in fourth and third and second decades of life with age range of 17 to 72 years (Figure 1). Papillary serous Cystadenocarcinoma was the most common malignant tumour observed, constituting $5(19.2 \%)$. The commonest benign neoplasm was papillary serous Cystadenoma 3(11.5\%). Germ cell tumours were represented by 2 cases of mature cystic teratoma $(7.7 \%)$.

\section{DISCURSION}

The current study reveals that $42.3 \%$ of the oophorectomies were non-neoplastic lesions. This finding concurs with the data from Saudi Arabia where Mansoor ${ }^{8}$ and Abdullah et al reported in their study that non-neoplastic lesions comprised $47.5 \%$ and $38.2 \%$ respectively. In the present study, benign lesions were $19.2 \%$ and malignant lesions accounted for $38.5 \%$. This figure is slightly different from the findings of other authors ${ }^{9-12}$ and may be explained by the rather short study period. The most common non-neoplastic lesion in this study was Corpus luteum cyst $(15.4 \%)$. These can rupture and mimic an ovarian neoplasm as reported by Hallatt et $a l^{13}$ In addition, an ovarian ectopic pregnancy was also found in this study as reported by Ito et al. ${ }^{14}$ Among different histological types, the most common category of ovarian neoplasms encountered in our series was tumours of surface epithelial origin (34.6\%), followed by sex cord stromal tumour $(15.4 \%)$ and germ cell tumours $(7.7 \%)$. Studies from other centres in
Nigeria and other countries also show that surface epithelial tumours were the most common ovarian neoplasm. ${ }^{9,11,15-17}$ The most common benign ovarian neoplasm in this study was serous cystadenoma (11.5\%) and the most common malignant neoplasm was Papillary serous Cystadenocarcinoma (19.2\%). This finding concurs with previous studies by Gupta et $\mathrm{al}^{11}$ and Khan et al ${ }^{18}$ which show similar findings.

On the other hand, our data is dissimilar from some studies from within Nigeria ${ }^{19}$ as well as from other countries. ${ }^{12,}{ }^{19,20}$ Fubara et a $l^{9}$ have slightly different findings of lymphoma $(57.1 \%)$, germ cell tumours $(22.9 \%)$ followed by surface epithelial tumours (11.4\%). Differences in the study period and variation in the diagnostic criteria as well as different study design may explain the differences. Most ovarian neoplasm occur in women of reproductive age group, as in this study. ${ }^{20}$ Benign ovarian neoplasm occur at any age whereas malignant ovarian neoplasm were more common in elderly. ${ }^{12}$ Abdullah et al found that the risk that an ovarian neoplasm was malignant increases from ages 20-29years and 60-69 years. The present study shows a similar trend. Germ cell tumours were the most common tumour in the second decade of life; this is similar to findings by Abdullah et al. ${ }^{9}$

\section{CONCLUSION:}

The most common non-neoplastic ovarian lesion was Corpus luteum cyst and the most common benign and malignant ovarian neoplasm was papillary serous Cystadenoma and papillary serous Cystadenocarcima respectively.

A further review may be needed in the future to compare epidemiologic trends in the environment.

\section{REFERENCES}

1. Franco EL, Franco ED, Ferenczy A. Cervical cancer: epidemiology, prevension and the role of human papilloma virus infection. Canadian Med Ass J 2001; 164:1071-1025.

2. Monaghan JM. Malignant disease of the ovary in: Edmonds DK editor. Dewhurst's textbook of Obstetrics and Gynaecology 
for postgraduate, $6^{\text {th }}$ Ed. Blackwell science publisher, Oxford. 1999. p. 590-601

3. Julie A. Irving . Philip B. Clement Nonneoplastic Lesions of the Ovary in: Kurman RJ, Ronnett BM, Ellenson LH. editors Blaustein's Pathology of the Female Genital tract, $6^{\text {th }}$ ed. : New York, NY 10013, USA: Springer Science Business Media; 2011.p.580-619

4. Drapkin RI Hecht JL Pathogenesis of Ovarian Cancer in: Crum CP, Nucci MR, Lee KR. editors. Diagnostic Gynecologic and Obstetric Pathology.Philadelphia, PA. USA: Saunders Elsevier; 2011, $2^{\text {nd }}$ ed. p. 758-776

5. Ellenson RH, Pirog EC. The Female Genital Tract in:Kumar V, Abbas A, and Fausto N. editors. Robbins and Cotran Pathologic Basis of Disease. 8th ed. Philadelphia, PA. USA: Saunders Elsevier;2010. p. 1024-1036

6. Ejeokam GC, Abdulla F, El-sakka M, Dauleh W, Haseeb F. Gynaecological Malignancies in Qatar. East Afr med J 1994;71:777-781

7. MandongBM,Ujah IAO. A Ten-year review of gynaecological malignancies in Jos University Teaching Hospital, Jos, Nigeria (1990-1999). Sahel Med J 2003; $6(2): 49-52$.

8. Mansoor I. Ovarian diseases at King Abdul-Aziz University Hospital. Saudi Med J 2002; 23:1551-1552.

9. Abdullah L S, Bondagji N S. Histopathological pattern of ovarian neoplasms and their age distribution in the western region of Saudi Arabia. Saudi Med J 2012; 33(1) : 61-65.

10. Tavassoli FA, Devilee P. WHO Classification of tumours. Pathology and Genetics, Tumours of Breast and Female Genital Organs. Lyon: IARC Press 2003.

11. Gupta N, Bisht D, Agarwal AK, Sharma VK. Retrospective and prospective study of ovarian tumours and tumour-like lesions. Indian J PatholMicrobiol 2007; 50:525527.

12.Jha R, Karki S. Histological pattern of ovarian tumours and their age distribution. Nepal Med Coll J 2008; 10(2):81-85.

13. Hallatt JG, Steele CH Jr, Snyder M. Ruptured corpus luteum with hemoperitoneum: a study of 173 surgical cases. Am J ObstetGynecol 1984; 149:5-9.

14. Ito H, Ishihara A, Koita H, Hatakeyama K, Seguchi T, Akiyama $\mathrm{Y}$ et al. Ovarian pregnancy: report of four cases and review of the literature. PatholInt 2003; 53(11):806-809

15. Gadanci H S, Mohammed AZ, Uzoho C C, Jido T A, Ochicha O. Gynaecological Malignancies Seen in Tertiary Health Facility in Kano, Northern Nigeria. Trop J ObstetGynaecol, 2003: 20(2):105-108.

16. Airede LR, Malami SA. A Five-Year Review of Female Genital Tract Malignancies in Sokoto, Northwestern Nigeria. Mary Slessor Jour of Med, 2005;5(1):51-56.

17. Mohammed A, Ahmed SA, Oluwole OP, Avidime S. Malignant Tumours of Female Genital Tract in Zaria, Nigeria: Analysis of 513 cases. Annals of African Medicine, 2006;5(2):93-96.

18. Khan AA, Lugman M, Jamal S, Mamoon $\mathrm{N}$, Mushtag S. Clinicopathological analysis of ovarian tumours. Pak J Pathol 2005; 16:28-32.

19. Fubara D S, Ikimalo J, Etebu E. Ovarian malignancies in childhood and adolescents: Experience from Port Harcourt, Nigeria. Nigj surg sci. 2009; 19(2):95-100.

20. Ahmad Z, Kayani N, Hasan SH, Muzaffar S, Gill MS. Histological pattern of ovarian neoplasm. J Pak Med Assoc 2000; 50: 416419. 